\title{
8 Ethics Committee Vote
}

Is the existence of an ethics vote a mandatory prerequisite for the activation of a site and the start of data collection at this site?

Whether an ethics vote is required or not depends on the nature of the research project and the persons involved. The GDPR does not demand an ethics vote for the admissibility of a data processing for the purpose of the scientific research. The entire GDPR takes only in recital 33 reference to the adherence to ethical standards for the special case of a Broad Consent. Nevertheless, the requirement for an ethics vote may follow from specific EU law or German law depending on the type of study and the persons involved (cf. tab. 1).

It should be noted, that whenever the research project is carried out by physicians, the regulations of medical professional law must be followed. In a Model Professional Code Of Conduct (MBO-Ä) which is not legally binding, the German Medical Association (Bundesärztekammer) has formulated guidelines which have been converted into a legally binding professional code of conduct for doctors by the respective medical associations in all seventeen German chamber districts. 
Tab. 1 Requirements for an ethics vote depend on the type of study and the applicable law

\begin{tabular}{|c|c|c|}
\hline Type of Study & EU law & German law \\
\hline $\begin{array}{l}\text { Clinical trial (medicinal } \\
\text { products) }\end{array}$ & $\begin{array}{l}\text { Article } 3 \text { para. } 2 \text { lit. a) Direc- } \\
\text { tive } 2001 / 20 / \text { EC } \\
\text { Article } 3 \text { lit. a), Article } 4 \\
\text { subparagraph } 1 \text { and } 2 \text { Regula- } \\
\text { tion 536/2014/EU }\end{array}$ & $\begin{array}{l}\text { Section } 40 \text { paragraph } 1 \\
\text { sentence } 2 \mathrm{AMG}\end{array}$ \\
\hline $\begin{array}{l}\text { Clinical trial (medical } \\
\text { devices) }\end{array}$ & $\begin{array}{l}\text { Article } 15 \text { Directive } 93 / 42 / \mathrm{EC} \\
\text { Article } 10 \text { Directive } 90 / 385 / \mathrm{EC} \\
\text { Article } 62 \text { para. } 3 \text { lit. b) Regulation } \\
\text { (EU) } 2017 / 745 \\
\text { Article } 58 \text { para. } 5 \text { lit. b) Regulation } \\
\text { (EU) } 2017 / 746\end{array}$ & $\begin{array}{l}\text { Section 20, paragraph } 1 \text {, } \\
\text { sentence 1, var. } 1 \text { in } \\
\text { conjunction with } \\
\text { Section } 22 \text { MPG }\end{array}$ \\
\hline $\begin{array}{l}\text { Application of radioactive } \\
\text { substances or ionising } \\
\text { radiation to humans for the } \\
\text { purpose of medical research }\end{array}$ & $\begin{array}{l}\text { Article } 28 \text { lit. a) in conjunction } \\
\text { with Article } 55 \text { para. } 2 \text { lit. e) } \\
\text { Council Directive 2013/59/ } \\
\text { EURATOM }\end{array}$ & $\begin{array}{l}\text { Section 31, paragraph 4, } \\
\text { no. } 5 \text { in conjunction with } \\
\text { Section } 36 \text { Radiation } \\
\text { Protection Act (StrlSchG) }\end{array}$ \\
\hline
\end{tabular}

Section 15 para. 1 of the $\mathrm{MBO}-\ddot{A}$ reads as follows:

"Physicians who participate in a research project which invades the mental or physical integrity of a human being, or uses human body material or data which can be traced to a particular individual, must ensure that advice on questions of professional ethics and professional conduct associated with the project is obtained from an Ethics Committee established at the responsible Chamber of Physicians, or from another independent, interdisciplinary Ethics Committee set up according to state law, before conducting the research. The same applies prior to conducting legally permitted research on viable human gametes and living embryonic tissue."

The Professional Codes Of Conduct for physicians in Mecklenburg-Western Pomerania and Berlin, for example, stipulate the same or comparable requirement for an ethics vote.

In what form and to what extent can or must the data processor (TTP) prove the existence of the ethics vote and possibly other legal bases as a prerequisite? Who bears which responsibility?

The responsibility for obtaining the necessary documents, such as consents, approvals and ethical votes, lies with the person responsible for the research project, in the case of clinical trials the sponsor, but not the TTP. Should TTP nevertheless wish to insure that all documents are available, a simple copy or scan would suffice for this proof, provided that there are no reasonable doubts as to their authenticity. 
Part II of the legal opinions: Detailed Questions on organisational and technical measures

What is the legal (not: contractual) minimum standard before the data processor can perform hisservices in conformity with the law, what requirements must be met before the TTP "activates" a study centre, a study or a project?

Independent data trust agencies, such as the TTP, are not regulated by special laws when it comes to ethical votes. Trust agencies should conclude necessary contracts, for example, contracts on data processing according to Art. $28 \mathrm{GDPR}$, if this is necessary in an individual case. Depending on the tasks of the TTP and its legal independence an agreement according to Article 26 or Article 28 GDPR may have to be in effect before personal data is being processed.

In EU projects: To what extent is the TTP obliged to check the correctness of the ethics vote in the national language (e.g. Greek), or is work on a "basis of trust" sufficient?

As TTP is not responsible for the accuracy, authenticity and efficacy of any ethics vote or approval, no review is required by law. However, a check and, if necessary, a verified translation is recommended in order to limit a possible liability. 